\title{
Incidence of mutations in the PARK2, PINKI, PARK7 genes in Polish early-onset Parkinson disease patients
}

\section{Częstość występowania mutacji w genach PARK2, PINK1, PARK7 w grupie polskich pacjentów z chorobq Parkinsona o wczesnym poczq̨tku}

Dariusz Koziorowski', Doroła Hoffman-Zacharska ${ }^{2,3}$, Jarosław Sławek ${ }^{4,5}$, Zygmunt Jamrozik6, Piotr Janik6, Anna Potulska-Chromik6, Anna Roszmann ${ }^{4,5}$, Renata Tatai', Jerzy Bal', Andrzej Friedman'

\author{
'Department of Neurology, Faculty of Health Science, Medical University of Warsaw, Poland \\ ${ }^{2}$ Department of Medical Genetics, Institute of Mother and Child, Warsaw, Poland \\ 3 Institute of Genetics and Biotechnology, Warsaw University, Poland \\ ${ }^{4}$ Department of Neurological and Psychiatric Nursing, Medical University, Gdansk, Poland \\ ${ }^{5}$ Department of Neurology, St. Adalbert Hospital, Gdansk, Poland \\ ${ }^{6}$ Department of Neurology, Medical University of Warsaw, Poland
}

Neurologia i Neurochirurgia Polska 2013; 47, 4: 319-324

DOI: 10.5114/ninp.2013.36756

\begin{abstract}
Background and purpose: Parkinson disease (PD) is a complex disease, comprising genetic and environmental factors. Despite the vast majority of sporadic cases, three genes, i.e. PARK2, PINK1 and PARK7 (DJ-1), have been identified as responsible for the autosomal recessive form of early-onset Parkinson disease (EO-PD). Identified changes of these genes are homozygous or compound heterozygous mutations. The frequency of PARK2, PINK1 and PARK 7 mutations is still under debate, as is the significance and pathogenicity of the single heterozygous mutations/variants, which are also detected among PD patients. The aim of the study was to analyze the incidence of autosomal recessive genes $P A R K 2$, PINK1, PARK7 mutations in Polish EO-PD patients.

Material and methods: The analysis of the PARK2, PINK1 and $P A R K 7$ genes was performed in a group of 150 Polish EO-PD patients (age of onset $<45$ years). Mutation analysis was based on sequencing and gene dosage abnormality identification.

Results: Mutations were identified only in the PARK2 and PINK1 genes with the frequency of $4.7 \%$ and $2.7 \%$ of subjects, respectively. In $P A R K 2$, point mutations and exons'
\end{abstract}

\section{Streszczenie}

Wstęp i cel pracy: Pomimo że wśród osób z chorobą Parkinsona $(\mathrm{ChP})$ dominują przypadki sporadyczne, trzy geny: PARK2, PINK1 i PARK7, zostały scharakteryzowane jako odpowiedzialne za występowanie autosomalnie recesywnej postaci ChP o wczesnym początku. Mutacje w tych genach mogą mieć charakter zmian homozygotycznych lub heterozygotycznych złożonych, dotyczących obu alleli. U części pacjentów identyfikuje się tylko mutacje jednoalleliczne, a ich udział w patogenezie $\mathrm{ChP}$ pozostaje wciąż sprawą kontrowersyjną. Celem badania jest analiza częstości występowania i rodzaju mutacji w genach PARK2, PINK1 i PARK7 w polskiej populacji chorych na $\mathrm{ChP}$ o wczesnym początku.

Materiał i metody: Analizę występowania mutacji w genach PARK2, PINK1 i PARK7 przeprowadzono w grupie 150 polskich pacjentów z $\mathrm{ChP}$ o wczesnym początku (wiek w chwili wystąpienia objawów choroby $<45$ lat). Badanie obejmowało analizę sekwencji kodujących wszystkich genów oraz identyfikację rearanżacji (delecje/duplikacje) w ich obrębie. W analizach mutacji wykorzystano bezpośrednie sekwencjonowanie genów oraz metodę MLPA (multiplex ligation-dependent probe amplification).

Correspondence address: Dariusz Koziorowski, MD, PhD, Medical University of Warsaw, Department of Neurology, 8 Kondratowicza St, 03-242 Warsaw, Poland, phone + 4822 3265815, fax + 4822 3265815, e-mail: dkoziorowski@esculap.pl

Received: 6.06.2012; accepted: 4.12 .2012 
rearrangements, and in PINK1 only missense mutations were detected. In both genes mutations were found as compound heterozygous/homozygous and single heterozygous. EO-PD patients' genotype-phenotype correlation revealed similarities of clinical features in mutation carriers and non-carriers. Conclusions: The frequency of the PARK2, PINK1, PARK7 mutations among Polish EO-PD patients seems to be low. The role of single heterozygous mutations remains a matter of debate and needs further investigations.

Key words: early onset Parkinson disease, PARK2, PINK1, PARK7.
Wyniki: Mutacje zidentyfikowano tylko w genach PARK2 i PINK1 z częstością odpowiednio $4,7 \%$ i $2,7 \%$. W genie $P A R K 2$ znaleziono mutacje punktowe oraz rearanżacje, natomiast w PINK1 tylko mutacje punktowe typu zmiany sensu. Zidentyfikowane mutacje występują zarówno jako heterozygotyczne złożone/homozygotyczne, jak i jednoalleliczne. Korelacja fenotypowo-genotypowa wśród pacjentów z ChP o wczesnym początku jest podobna zarówno dla nosicieli, jak i dla osób bez mutacji.

Wnioski: Częstość występowania mutacji w genach PARK2, PINK1 i PARK7 wśród polskich pacjentów z wczesną postacią $\mathrm{ChP}$ wydaje się mała. Rola pojedynczych heterozygotycznych mutacji w patogenezie $\mathrm{ChP}$ o wczesnym początku pozostaje sprawą dyskusyjną i w celu jej wyjaśnienia potrzebne są dalsze badania.

Słowa kluczowe: choroba Parkinsona o wczesnym początku, PARK2, PINK1, PARK7.

sonism, clinical characteristics include psychiatric symptoms, short stature, and brachydactyly [14]. The incidence of PARK 7 mutations in some ethnic groups has been estimated as $1-2 \%$ of EO-PD [15-18].

In all EO-PD genes (PARK2, PINK1 and PARK7) mutations were identified as homozygous, compound heterozygous and single heterozygous. The role of single heterozygous variants in "recessive genes" remains still controversial, as they are found in PD patients and healthy controls $[19,20]$.

\section{Material and methods}

\section{Subjects}

One hundred and fifty EO-PD patients ( $42 \%$ females, $58 \%$ males) of Polish origin from different centers covering central and northern and southern Poland with onset of PD before the age of 45 entered the study. Neurologists experienced in diagnostics of movement disorders performed neurological examination. The clinical diagnosis of PD patients was established according to UK Parkinson's disease Brain Bank criteria [21]. The patients' age ranged from 25 to 68 years (mean: 45.8; standard deviation [SD]: 8.4), their age at disease onset varied between 20 and 44 years (mean: 36.8; SD: 5.4) and disease duration ranged from 0.5 to 30 years (mean: 8.9; SD: 6.3). Most patients presented a sporadic form of PD $(80 \%)$, while the familial cases constituted another $20 \%$. Patients were classified as familial cases if at least one of their first- or second-degree rela- 
Table 1. Clinical features of patients with early-onset Parkinson disease: non-carriers and PARK2, PINKI gene mutation carriers

\begin{tabular}{|lccc|}
\hline & Non-carriers & Parkin mutation carriers & Pink mutation carriers \\
\hline Number & 141 & 7 & 4 \\
\hline Positive family history [\%] & 20 & 57 & 25 \\
\hline Women [\%] & 41 & 57 & 75 \\
\hline Age at onset [years]; mean \pm SD & $34.9 \pm 4.9$ & $32.1 \pm 5.4$ & $18.0 \pm 14.1$ \\
\hline Disease duration [years]; mean \pm SD & $7.9 \pm 5.9$ & $9.7 \pm 7.7$ & $2.7 \pm 0.3$ \\
\hline Hoehn and Yahr stage & $2.0 \pm 0.8$ & $2.3 \pm 0.7$ & $666 \pm 400$ \\
\hline Daily dose of levodopa [mg]; mean \pm SD & $784 \pm 494$ & $557 \pm 528$ & $29.5 \pm 0.7$ \\
\hline MMSE score & $28.7 \pm 1.8$ & $29.5 \pm 1.2$ & 100 \\
\hline Dyskinesia [\%] & 50 & 43 & 50 \\
\hline Fluctuations [\%] & 58 & 57 & 0 \\
\hline Symptoms at onset [\%]: & & 43 & 50 \\
\hline Rest tremor & 46 & 0 & 50 \\
\hline Bradykinesia & 25 & 43 & 0 \\
\hline Rigidity & 17 & 14 & \\
\hline Other (pain, dystonia) & 13 & 43 & \\
\hline
\end{tabular}

SD - standard deviation; MMSE - Mini-Mental State Examination

tives had a diagnosis of PD but clear AR pattern of disease inheritance was observed in 3 cases (2\%) only. Clinical data of the patients are presented in Table 1.

\section{Control group}

The control group consisted of 230 unrelated subjects (56\% females, $44 \%$ males), healthy volunteers with no evidence of neurological/neurodegenerative disorder history in the family, aged from 18 to 73 years (mean: 31; SD: 11.2). All participants signed an informed consent form. The ethics committees of the Warsaw Medical University and Institute of Mother and Child approved the study.

\section{Methods}

Molecular analysis was performed on genomic DNA extracted from patients' venous blood. All coding exons of the PARK2, PARK7 and PINK1 genes were amplified by polymerase chain reaction (PCR) and products directly sequenced. In the case of novel mutations in the PINK1 gene, the direct sequencing of appropriate exons in the control group was performed. To detect rearrangements of the genes, multiplex ligation-dependent probe amplification (MLPA) was performed using the com- mercially available kits SALSA MLPA P051/P052 (MRC-Holland). Sequence analysis was performed using Surveyor v.3.2 software in comparison to reference sequences: NM_004562, NM_007262, NM_032409 [NCBIRefSeq,http://www.ncbi.nlm.nih. gov/nuccore]. MLPA peak analysis, normalization and calculation of dosage ratio were performed with the Gene Markerv.1.51 software (both SoftGenetics LLC). Mutations were referred to data in Human Gene Mutation Database (HGMD Professional; http://www.hgmd. cf.ac.uk) and Parkinson Disease Mutation Database (PDmutDB; http://www.molgen.ua.ac.be/PDmutDB). Statistical analysis was performed using SPSS version 14.0 software. The impact of the newly identified PINK1 gene mutations on the protein structure and function was analysed with the PolyPhen-2 v.2.1 software using the HumVar model (http://genetics.bwh.harvard.edu/pph2).

\section{Results}

Mutations were found only in the PARK2 and PINK1 genes. In $P A R K 2$, changes were detected in 7 patients (4.7\%); the frequency of PINK1 mutations was even lower $(2.7 \%)$.

In the PARK2 gene, the mutations were found as homozygous in one case, compound heterozygous in four 
Table 2. Mutation in the PARK2 and PINKI gene identified among patients with early-onset Parkinson disease (EOPD)

\begin{tabular}{|c|c|c|c|c|c|c|}
\hline ID & Sex & $\begin{array}{c}\text { Age } \\
\text { at onset } \\
\text { [years] }\end{array}$ & $\begin{array}{l}\text { Parkinson } \\
\text { disease } \\
\text { in family }\end{array}$ & PARK2 & PARK7 & PINK1 \\
\hline 31703 GA & $\mathrm{F}$ & 24 & None & Ex3_4del/p.Gln34ArgfsX5 & $-/-$ & $-/-$ \\
\hline $30716 \mathrm{KL}$ & M & 26 & $\begin{array}{l}\text { Two brothers } \\
\text { (EO-PD) }\end{array}$ & Ex3del/Ex4_7del & $-/-$ & $-1-$ \\
\hline $29293 \mathrm{KE}$ & $\mathrm{F}$ & 33 & None & Ex2_5dup/p.Lys211Asn & $-/-$ & $-1-$ \\
\hline $24702 \mathrm{~KB}$ & $\mathrm{~F}$ & 37 & None & p.Gln34ArgfsX5/p.Gln34ArgfsX5 & $-/-$ & $-1-$ \\
\hline $20300 \mathrm{BM}$ & $\mathrm{F}$ & 31 & None & Ex4_7del/p.Gln34ArgfsX5 & $-1-$ & $-1-$ \\
\hline 19134 KW & $\mathrm{M}$ & 36 & Father (LOPD) & Ex2dup/- & $-1-$ & $-/-$ \\
\hline $26260 \mathrm{ZR}$ & M & 38 & None & p.Arg275Trp/- & $-/-$ & $-1-$ \\
\hline $19642 \mathrm{LH}$ & $\mathrm{F}$ & 28 & $\begin{array}{l}\text { Two brothers } \\
\text { (EOPD) }\end{array}$ & $-/-$ & $-/-$ & p.Ile3658Asn/p.Ile368Asn \\
\hline $17788 \mathrm{RM}$ & $\mathrm{F}$ & 31 & None & $-/-$ & $-1-$ & p.Lys186Asn/- \\
\hline $16655 \mathrm{AI}$ & M & 28 & None & $-/-$ & $-/-$ & p.Ser535Leu/- \\
\hline 23866 OJ & $\mathrm{F}$ & 39 & None & $-/-$ & $-1-$ & p.Gly411Ser/- \\
\hline
\end{tabular}

cases and in 2 cases as single heterozygous (Table 2). Thus, the frequency of the PARK2 mutations in our EO-PD concerns about $4.0 \%$ of alleles. In one patient we also found homozygous mutation p.Asp394Asn/p.Asp394Asn. This abnormality, if it occurs as single heterozygous, is considered as polymorphism [rs1801334, dbSNP, http:// www.ncbi.nlm.nih.gov/SNP], but as homozygous it shows an association with familial PD [22,23].

In the PINK1 gene, potentially pathogenic variants were detected only in four patients: one case of homozygous mutation p.Ile368Asn/ p.Ile368Asn and heterozygous p.Ser535Leu/- (both novel, not detected in control Polish group) and two known, but controversial, single heterozygous changes p.Lys186Asn and p.Gly411Ser. All identified mutations were localized in functional domains of PINK1 protein. The in silico analysis performed using the PolyPhen-2/HumVar tool confirmed potential pathogenicity of both novel mutations p.Ile368Asn and p.Ser535Leu. These two substitutions were predicted as "probably damaging", with the corresponding probability scores reaching 0.99 and 1.0 .

EO-PD patients' genotype-phenotype correlation revealed similarities of clinical features in mutation carriers and non-carriers (Table 1). Asymmetrical tremor was a dominant symptom at the onset of the disease in both groups. The patient with single $P A R K 2$ mutation and 25-year duration of disease had severe fluctuations and dyskinesias. Both subjects with double mutation had no dyskinesias. Response to levodopa treatment was excellent for all of them.

\section{Discussion}

Mutations in all analyzed genes were found in $7.4 \%$ of examined EO-PD patients. This frequency is similar to the mutation frequency of PARK2, PINK1, PARK7 genes $(6.9 \%)$ in a large study $(n=953 \mathrm{PD}$ patients, age at onset $<51$ years) [3]. Analysis of 187 Dutch patients with PD (age at onset $\leq 50$ ) revealed $8.5 \%$ of subjects with mutation of these genes [24], but analysis of a group of 127 Chinese patients with EO-PD showed mutations in $18.1 \%$ of cases [25]. This variable incidence may reflect the ethnic differences.

Published data on PARK2 mutations in sporadic young onset cases (age at onset $<45$ years) also give a variable frequency. Analysis of 146 Italian unrelated EO-PD patients (disease onset $<40$ ) found $8.2 \%$ of cases with homozygous/compound heterozygous point mutations and/or exon rearrangements and $2.7 \%$ of subjects with a single mutation in the PARK2 gene [26]. Again, in a Chinese group of $127 \mathrm{EO}-\mathrm{PD}$ patients any mutation was found in $12.6 \%$ of cases [25]. Hakansson et al. [27] analyzed a group of 60 Swedish patients with EO-PD and described only one case with a single 
mutation (1.5\%), but among 187 Dutch patients (age at onset $\leq 50)$ this frequency was higher (5.9\%) [24]. Other EO-PD patient surveys presented PARK2 mutations at a frequency of $2.7 \%$ in Queensland, Australia, $6.6 \%$ in South African and 5.5\% in Korean cohorts [28$30]$. Frequency of $P A R K 2$ mutation in a cohort of mixed populations $(n=953)$ was $6.3 \%$ [3]. Those data, as well as ours (4.7\%), may suggest that the PARK2 gene mutations are less frequent than has been expected based on previous studies [11].

PINK1 gene mutations are probably very rare, with local higher distribution. Alcalay et al. [3] found no PINK1 mutation in 953 EO-PD patients. One percent of subjects with PINK1 mutation was found in a Dutch and $3.1 \%$ in a Chinese EO-PD population [24,25]. Our results with $2.7 \%$ of patients with mutations seem to be about average and may suggest that the PINK1 gene mutations are less frequent than in earlier reports.

The PARK 7 mutations are rare, representing perhaps less than 1-2\% in EO-PD cases [15-18].

A large study of a group of $953 \mathrm{PD}$ patients with age at onset $<51$ years showed mutations of $P A R K 7$ genes in $0.2 \%$ of subjects [3]. In the Chinese cohort of sporadic EO-PD patients mutations were more frequent and were found in $2.4 \%$ of subjects [25]. In our cohort of 150 EO-PD patients, similarly to some other studies, no mutations in the $P A R K 7$ gene were found $[1,30]$.

As reported elsewhere, we found the phenotype of the $P A R K 2$ mutation carriers indistinguishable from non-carriers. The clinical hallmark of the PARK2 mutation carriers was a good response to levodopa and a lack of dementia. Lohmann et al. [32] analyzed groups of 44 EO-PD patients with or without mutation and found no difference in both groups except for significantly lower daily doses of dopaminergic treatment in PARK2 mutation carriers. Typical clinical presentation of PINK1-PD is an early-onset parkinsonism with slow progression, and excellent reaction to levodopa, not differing from typical PD features.

In our group we identified five patients with only a single heterozygous PARK2 or PINK1 mutations. Many authors have also found such mutations in their patients in these genes as well as in PARK7 [1,2,10,24]. There are several potential ways to elucidate this issue. A second mutation may be localized in regions of the gene that were not screened (promoter, introns) or in another gene that acts in the same pathway in the pathogenesis of PD. Some single heterozygous variants could act as lossof-function mutations by lowering the biological activity of the encoded protein (haploinsufficiency). But the most important thing is that these heterozygous mutations may result in increased risk for developing PD.

The frequency of heterozygous PARK2 mutations in healthy subjects is about 3.7\% [33]. These subjects could develop parkinsonian syndromes later [33]. PARK2, PINK1 and PARK7 genes underline the importance of mitochondrial dysfunction and oxidative stress in PD [34]. Positron emission tomography studies with the use of $18 \mathrm{~F}$-dopa showed a $20-30 \%$ reduction of its uptake when compared with controls, which may support the concept of increased risk of PD development in the next years for these carriers [35].

\section{Conclusions}

1. The frequency of the $P A R K 2, P I N K 1, P A R K 7$ mutations among Polish EO-PD patients seems to be low.

2. The role of single heterozygous mutations remains a matter of debate and needs further investigations.

\section{Acknowledgements}

This study was supported by the Polish Ministry of Science and Higher Education grants PBZ-KBN124/P05/2044 and N N402 279536.

\section{Disclosure}

Authors report no conflict of interest.

\section{References}

1. Wickremaratchi M.M., Knipe M.D., Sastry B.S., et al. The motor phenotype of Parkinson's disease in relation to age at onset. Mov Disord 2011; 26: 457-463.

2. Schrag A., Schott J.M. Epidemiological, clinical and genetic characteristics of early onset parkinsonism. Lancet Neurol 2006; 5: $355-363$

3. Alcalay R.N., Caccappolo E., Mejia-Santana H., et al. Frequency of known mutations in early-onset Parkinson disease. Arch Neurol 2010; 67: 1116-1122.

4. OMIM (TM Online Mendelian Inheritance in Man). McKusick-Nathans Institute of Genetic Medicine, Johns Hopkins University (Baltimore, MD) and National Center for Biotechnology Information, National Library of Medicine (Bethesda, MD). (01.2009).

5. Kitada T., Asakawa S., Hattori N., et al. Mutation in the parkin gene cause autosomal recessive juvenile parkinsonism. Nature 1998; 392: 605-608.

6. Valente E.M., Abou-Sleiman P.M., Caputo V., et al. Hereditary early-onset Parkinson's disease caused by mutations in PINK1. Science 2004; 304: 1158-1160. 
7. Bonifati V., Rizzu P., van Baren M.J., et al. Mutations in the DJ-1 gene associated with autosomal recessive early-onset parkinsonism. Science 2003; 299: 256-259.

8. Khan N.L., Brooks D.J., Pavese N., et al. Progression of nigrostriatal dysfunction in a parkin kindred: an $[18 \mathrm{~F}]$ dopa PET and clinical study. Brain 2002; 125: 2248-2256.

9. Khan N.L., Graham E., Critchley P., et al. Parkin disease: a phenotypic study of a large case series. Brain 2003; 126: 1279-1292.

10. Tan E.K., Skipper L.M. Pathogenic mutation in Parkinson's disease. Hum Mutat 2007; 28: 641-653.

11. Lucking C.B., Durr A., Bonifati V., et al. Association between early-onset Parkinson's disease and mutations in the parkin gene. French Parkinson's disease Genetic Study Group. N Engl J Med 2000; 342: 1560-1567.

12. Bonifati V., Rohe C.F., Breedveld G.J., et al. Early-onset parkinsonism associated with PINK1 mutations: frequency, genotypes, and phenotypes. Neurology 2005; 65: 87-95.

13. Li Y., Tomiyama H., Sato K., et al. Clinicogenetic study of PINK1 mutations in autosomal recessive early-onset parkinsonism. Neurology 2005; 64: 1955-1957.

14. Dekker M.C., Galjaard R.J., Snijders P.J., et al. Brachydactyly and short stature in a kindred with early-onset parkinsonism. Am J Med Genet A 2004; 130A: 102-104.

15. Djarmati A., Hedrich K., Svetel M., et al. Detection of Parkin (PARK2) and DJ1 (PARK7) mutations in early-onset Parkinson disease: parkin mutation frequency depends on ethnic origin of patients. Hum Mutat 2004; 23: 525.

16. Clark L.N., Afridi S., Mejia-Santana H., et al. Analysis of an early-onset Parkinson's disease cohort for $D J-1$ mutations. Mov Disord 2004; 19: 796-800.

17. Hedrich K., Djarmati A., Schäfer N., et al. DJ-1 (PARK7) mutations are less frequent than Parkin (PARK2) mutations in earlyonset Parkinson disease. Neurology 2004; 62: 389-394.

18. Ibáñez P., Michele G., Bonifati V., et al. Screening for DJ-1 mutations in early onset autosomal recessive parkinsonism. Neurology 2003; 61: 1429-1431.

19. Klein C., Lohmann-Hedrich K., Rogaeva E., et al. Deciphering the role of heterozygous mutations in genes associated with parkinsonism. Lancet Neurol 2007; 6: 652-662.

20. Nuytemans K., Theuns J., Cruts M., et al. Genetic etiology of Parkinson disease associated with mutations in the $S N C A$, PARK2, PINK1, PARK7, and LRRK2 genes: a mutation update. Hum Mutat 2010; 31: 763-780.

21. Hughes A.J., Daniel S.E., Lees A.J. Improved accuracy of clinical diagnosis of Lewy body Parkinson's disease. Neurology 2001; 57: 1497-1499.

22. Lucking C.B., Chesneau V., Lohmann E., et al. Coding polymorphisms in the parkin gene and susceptibility to Parkinson disease. Arch Neurol 2003; 60: 1253-2256.

23. Koziorowski D., Hoffman-Zacharska D., Sławek J., et al. Low frequency of the PARK2 gene mutations in Polish patients with the early-onset form of Parkinson disease. Parkinsonism Relat Disord 2010; 16: 136-138.

24. Macedo M.G., Verbaan D., Fang Y., et al. Genotypic and phenotypic characteristics of Dutch patients with early onset Parkinson's disease. Mov Disord 2009; 24: 196-203.
25. Guo J.F., Zhang X.W., Nie L.L., et al. Mutation analysis of Parkin, PINK1 and DJ-1 genes in Chinese patients with sporadic early onset parkinsonism. J Neurol 2010; 257: 1170-1175.

26. Sironi F., Primignani P., Zini M., et al. Parkin analysis in early onset Parkinson's disease. Parkinsonism Relat Disord 2008; 14: 326-333.

27. Hakansson A., Belin A.C., Stiller C., et al. Investigation of genes related to familial forms of Parkinson's disease - with focus on the Parkin gene. Parkinsonism Relat Disord 2008; 14: 20-22.

28. Mellick G.D., Siebert G.A., Funayama M., et al. Screening PARK genes for mutations in early-onset Parkinson's disease patients from Queensland, Australia. Parkinsonism Relat Disord 2009; 15: 105-109.

29. Bardien S., Keyser R., Yako Y., et al. Molecular analysis of the parkin gene in South African patients diagnosed with Parkinson's disease. Parkinsonism Relat Disord 2009; 15: 116-121.

30. Choi J.M., Woo M.S., Ma H.I., et al. Analysis of PARK genes in a Korean cohort of early-onset Parkinson disease. Neurogenetics 2008; 9: 263-269.

31. Hiroyuki T., Yuanzhe L., Hiroyo Y., et al. Mutation analysis for DJ-1 in sporadic and familial parkinsonism: screening strategy in parkinsonism. Neurosci Lett 2009; 455: 159-161.

32. Lohmann E., Thobois S., Lesage S., et al. A multidisciplinary study of patients with early-onset PD with and without parkin mutations. Neurology 2009; 72: 110-116.

33. Brüggemann N., Mitterer M., Lanthaler A.J., et al. Frequency of heterozygous Parkin mutations in healthy subjects: need for careful prospective follow-up examination of mutation carriers. Parkinsonism Relat Disord 2009; 15: 425-429.

34. Dodson M.W., Guo M. Pink1, Parkin, DJ-1 and mitochondrial dysfunction in Parkinson's disease. Curr Opin Neurobiol 2007; 17: 331-337.

35. Khan N.L., Valente E.M., Bentivoglio A.R., et al. Clinical and subclinical dopaminergic dysfunction in PARK6-linked parkinsonism: an 18F-dopa PET study. Ann Neurol 2002; 52: 849-853. 